\title{
Development of C-Arylcalix[4]resorcinarenes and C-Arylcalix[4]pyrogallolarenes as Antioxidant and UV-B Protector
}

\author{
Jumina $^{1, *}$, Dwi Siswanta ${ }^{1}$, Abdul Karim Zulkarnain ${ }^{2}$, Sugeng Triono ${ }^{1}$, Priatmoko ${ }^{1}$, Emmy Yuanita $^{3}$, Arif \\ Cahyo Imawan ${ }^{1}$, Nela Fatmasari ${ }^{1}$, and Ikhsan Nursalim ${ }^{1}$
}

${ }^{1}$ Department of Chemistry, Faculty of Mathematics and Natural Sciences, Universitas Gadjah Mada, Sekip Utara, Yogyakarta 55281, Indonesia

${ }^{2}$ Department of Pharmaceutical Technology, Faculty of Pharmacy, Universitas Gadjah Mada, Sekip Utara, Yogyakarta 55281, Indonesia

${ }^{3}$ Department of Chemistry, Faculty of Mathematics and Natural Sciences, Universitas Mataram, Jl. Majapahit No. 62, Mataram 83125, Indonesia

\section{*Corresponding author:}

email: jumina@ugm.ac.id

Received: July 24, 2017

Accepted: November 1, 2018

DOI: $10.22146 / \mathrm{ijc} .26868$

\begin{abstract}
Indonesia is rich with essential oils such as anise and clove leave oils. In respect to explore the potential utilization of these resources, it has been conducted the transformation of p-hydroxybenzaldehyde and vanillin (4-hydroxy-3-methoxy benzaldehyde) respectively derived from anise oil and clove leaves oil to a series of $C$ arylcalix[4]resorcinarenes and C-arylcalix[4]pyrogallolarene macrocycles. Treatment of these aldehydes with resorcinol in the presence of $\mathrm{HCl}$ in absolute ethanol at reflux for $8 \mathrm{~h}$ afforded C-4-hydroxyphenylcalix[4]resorcinarene (3a) and C-4-hydroxy-3-methoxy phenyl-calix[4]resorcinarene (3b) in good yields. When the aldehydes were treated with pyrogallol under the similar condition, the products were C-4-hydroxyphenyl calix[4]pyrogallolarene (3c) and C-4-hydroxy-3-methoxyphenylcalix[4]pyrogallolarene (3d) which were also obtained in excellent yields. Treatment of these calix[4]resorcinarenes and calix[4]pyrogallolarenes with cinnamoyl chloride and benzoyl chloride in pyridine afforded the corresponding cinnamate esters and benzoate esters in high yields. The resulted C-arylcalix-[4]resorcinarenes and C-arylcalix[4]pyrogallol arenes were subjected to antioxidant activity test using DPPH method and showed strong activity with $I_{50}$ values of $15-80 \mu \mathrm{g} / \mathrm{mL}$. In terms of the synthesized calix cinnamates, the compounds showed UV-B absorption with SPF values of 15-30 at a concentration of 25 ppm which demonstrate their potential to be applied as a UV-B protector. Furthermore, these compounds were also tested for their photostability on the UV-B region and the results showed that the compounds were still unstable under irradiation for $30 \mathrm{~min}$.
\end{abstract}

Keywords: calixresorcinarene; calixpyrogallolarene; antioxidant; UV-B protector

\section{- INTRODUCTION}

Exposure to ultraviolet (UV) radiation from the sun is known to cause health problems, such as sunburns, skin cancer and severe eye damage [1]. Sunscreen is a product containing compounds that can protect the skin from the effects of UV radiation emitted by the sun. The unit of sunscreen measurement is Sun Protection Factor (SPF) indicating the level of protection given by a material against UV radiation without burning the skin. Sunscreen protects the skin through both the absorption of UV radiation by the chromophore group of organic sunscreens and the absorption, reflection, and scattering of UV radiation by inorganic sunscreens [2-3]. Several studies have shown that the use of sunscreen could prevent the occurrence of skin diseases induced by the exposure of ultraviolet radiation, such as photoaging [4] and DNA damage (cancer) [5-6]. 
Sunscreen compounds are classified into two types, i.e., inorganic and organic sunscreens. Some examples of inorganic sunscreens are $\mathrm{ZnO}, \mathrm{MgO}, \mathrm{CaCO}_{3}$, and $\mathrm{TiO}_{2}$ [7], whereas organic sunscreens generally have conjugated benzene ring with carbonyl groups, such as oxybenzone and octyl methoxycinnamate [8]. Inorganic sunscreens, nowadays, are no longer used because it causes skin allergies and irritation. A study shows that $\mathrm{TiO}_{2}$ indeed damages skin cells [9]. On the other hand, the demand for organic sunscreen octyl methoxycinnamate keeps increasing as it does not damage DNA [10]. However, although the organic sunscreens are preferred, they have low stability. Meanwhile, one of the antioxidant working mechanisms is by preventing free radical produced by UV radiation. Through this mechanism, there is a trend for developing organic molecules having both antioxidant and sunscreen activity to be used as the active compounds for sunscreen products.

One of the potentials that can be used as sunscreen active compounds with broad-spectrum is calixarene derivatives either as calix[4] resorcinarenes or calix[4] pyrogallolarenes. Calixarenes have been widely used as ion selective electrode [11], transportation systems and sensor [12], complexes with metal ions [13], analytical and separation agents [14], the adsorbent of heavy metals and dichromate anions [15] and also as sunscreen [16]. These compounds are the tetracycline compounds resulted from a condensation of phenol and aldehyde derivatives. The fact that the compounds from phenol derivatives gives the advantages to work as a perfect antioxidant and the presence of a conjugated benzene with a carbonyl group will refine the sunscreen function even more. Calix[4]arenes are known to have high chemical, radiation, thermal stability and has relatively low toxicity, making it as a superior compound for sunscreen material [16]. Additionally, the fact that it has relatively large molecular weight is also another advantage, as it is consistent with the development trend of new innovative sunscreen compounds that tends to have molecular weights above $500 \mathrm{~g} / \mathrm{mol}$ [2]. The development of sunscreen compounds with large molecular weight is intended to prevent the absorption of the active compounds into the skin [17].

\section{- EXPERIMENTAL SECTION}

\section{Materials}

Materials employed for the synthesis were pyrogallol $\left(\mathrm{C}_{6} \mathrm{H}_{6} \mathrm{O}_{3}\right)$, resorcinol $\left(\mathrm{C}_{6} \mathrm{H}_{4}(\mathrm{OH})_{2}\right)$, 4hydroxybenzaldehyde $\left(\mathrm{C}_{7} \mathrm{H}_{6} \mathrm{O}_{2}\right)$, vanillin $\left(\mathrm{C}_{8} \mathrm{H}_{8} \mathrm{O}_{3}\right)$, ethanol $98 \%$, hydrochloric acid $37 \%$, pyridine $\left(\mathrm{C}_{5} \mathrm{H}_{5} \mathrm{~N}\right)$, cinnamoyl chloride $\left(\mathrm{C}_{9} \mathrm{H}_{7} \mathrm{OCl}\right)$ and distilled water. Materials used for the antioxidant and sunscreen activity tests were 1,1-diphenylpicryl-2-hydrazil (DPPH), butylated hydroxytoluene (BHT), methanol, dimethylsulfoxide $\left(\mathrm{C}_{2} \mathrm{H}_{6} \mathrm{OS}\right)$, and chloroform $\left(\mathrm{CHCl}_{3}\right)$. These materials were pro-analytic reagents from Merck except for distilled water.

\section{Instrumentation}

Equipments used in the study were a set of reflux, electric heater, magnetic stirrer, oven and laboratory glassware. Instruments used to characterize the synthesis products were the melting point instrument (Electrothermal 9100), FTIR spectrometer (ShimadzuPrestige 21), NMR spectrometers (NMR, JEOL JNMECA $500 \mathrm{MHz}$ ) and liquid-mass spectrometry chromatography (LC-MS Waters HPLC-SQD MS M3100). For antioxidant activity and sunscreen tests, shaker and UV-Vis spectrophotometer (UV Spectrophotometer Shimadzu UV 1800) were used.

\section{Procedure}

\section{Synthesis of C-4-hydroxyphenylcalix[4]resorcinarene} (3a)

Resorcinol (5.50 g; $0.05 \mathrm{~mol}$ ) was dissolved in $75 \mathrm{~mL}$ of ethanol $98 \%$ and $6.10 \mathrm{~g}$ of 4-hydroxybenzaldehyde (0.05 mol) was added afterward. After the mixture dissolved, $1 \mathrm{~mL}$ of $\mathrm{HCl} 37 \%$ was added dropwise. The mixture was then stirred and refluxed at $78^{\circ} \mathrm{C}$ for $20 \mathrm{~h}$. The mixture was let to cool off before distilled water was added. The precipitate formed was filtered and then dried to give as a red solid in $90 \%$ (m.p. $>290{ }^{\circ} \mathrm{C}$ ). FTIR $\left(\mathrm{KBr}, v ; \mathrm{cm}^{-1}\right)$ : $(-\mathrm{OH})$ 3356, $\left(\mathrm{C}_{s p 3}-\mathrm{H}\right) 2924$ and 2854, (C=C aromatic) 1612 and 1512, (C-H) 1427, (C-O) 1242. ${ }^{1} \mathrm{H}-\mathrm{NMR}$ (DMSO- $\left.d_{6} ; 500 \mathrm{MHz}\right) \delta(\mathrm{ppm}): 5.41(4 \mathrm{H}, \mathrm{s})$; $6.08(4 \mathrm{H}, \mathrm{s}) ; 6.30(J=12.95 \mathrm{~Hz}, 4 \mathrm{H}, \mathrm{d}) ; 6.47(J=9.1 \mathrm{~Hz}$, $4 \mathrm{H}, \mathrm{d}) ; 6.62(4 \mathrm{H}, \mathrm{s}) ; 8.45(4 \mathrm{H}, \mathrm{s}) ; 8.70(4 \mathrm{H}, \mathrm{s})$. 


\section{Synthesis of C-4-hydroxy-3-methoxyphenylcalix[4] resorcinarene (3b)}

Resorcinol ( $5.50 \mathrm{~g}$; $0.05 \mathrm{~mol}$ ) was dissolved in $75 \mathrm{~mL}$ ethanol $98 \%$ and $7.60 \mathrm{~g}$ of vanillin $(0.05 \mathrm{~mol})$ was added into the mixture afterward. After the mixture dissolved, 1 $\mathrm{mL}$ of $\mathrm{HCl} 37 \%$ was added dropwise. Further treatment was the same as that of compound $\mathbf{3 a}$ afforded compound 3b a light red solid in $84 \%$ (m.p. $>290^{\circ} \mathrm{C}$ ). FTIR ( $\mathrm{KBr}, v$; $\left.\mathrm{cm}^{-1}\right)$ : $(-\mathrm{OH})$ 3387, $\left(\mathrm{C}_{s p^{3}}-\mathrm{H}\right) 2939$ and 2854, $(\mathrm{C}=\mathrm{C}$ aromatic) 1612 and 1512, (C-H) 1427, $\left(-\mathrm{CH}_{3}\right) 1373$, (CO) $1280 .{ }^{1} \mathrm{H}-\mathrm{NMR}$ (DMSO- $\left.d_{6} ; 500 \mathrm{MHz}\right) \delta(\mathrm{ppm}): 3.52$ $(12 \mathrm{H}, \mathrm{s}) ; 5.40(4 \mathrm{H}, \mathrm{s}) ; 6.07(4 \mathrm{H}, \mathrm{s}) ; 6.13(4 \mathrm{H}, \mathrm{s}) ; 6.30(\mathrm{~J}=8.45$ $\mathrm{Hz}, 4 \mathrm{H}, \mathrm{d}) ; 6.32(4 \mathrm{H}, \mathrm{s}) ; 6.35(J=16.85 \mathrm{~Hz}, 4 \mathrm{H}, \mathrm{d}) ; 6.37$ $(4 \mathrm{H}, \mathrm{s})$; $8.47(4 \mathrm{H}, \mathrm{s})$; LCMS base peak: $730(\mathrm{~m} / \mathrm{z})$.

\section{Synthesis of C-4-hydroxyphenylcalix[4]pyrogallolarene (3c)}

Pyrogallol (1.89 g; $0.015 \mathrm{~mol}$ ) was dissolved in $30 \mathrm{~mL}$ ethanol $95 \%$ and $1.83 \mathrm{~g}(0.015 \mathrm{~mol})$ 4-hydroxy benzaldehyde was added afterward. After the mixture dissolved, $1 \mathrm{~mL}$ of $\mathrm{HCl} 37 \%$ was added dropwise. Further treatment was the same as that of compound $\mathbf{3 a}$ to afford compound $3 \mathrm{c}$ as an off white solid in $65 \%$ yield (m.p. > $\left.290{ }^{\circ} \mathrm{C}\right)$. FTIR $\left(\mathrm{KBr}, v ; \mathrm{cm}^{-1}\right):(-\mathrm{OH}) 3387,\left(\mathrm{C}_{s^{3}}-\mathrm{H}\right) 2924$, $(\mathrm{C}=\mathrm{O})$ 1700-1680, (C=C aromatic) 1635, (C-H) 1458, ($\mathrm{CH}_{2^{-}}$) 1373, (C-O phenol) 1242-1010. ${ }^{1} \mathrm{H}-\mathrm{NMR}$ (DMSO$\left.d_{6} ; 500 \mathrm{MHz}\right) \delta(\mathrm{ppm}): 5.52(4 \mathrm{H}, \mathrm{s}) ; 6.35(J=20.85 \mathrm{~Hz}$, $8 \mathrm{H}, \mathrm{d}) ; 6.33(\mathrm{~J}=17.95 \mathrm{~Hz}, 8 \mathrm{H}, \mathrm{d}) ; 5.52(2 \mathrm{H}, \mathrm{s}) ; 5.93(2 \mathrm{H}, \mathrm{s})$; $7.31(4 \mathrm{H}, \mathrm{s}) ; 7.48(4 \mathrm{H}, \mathrm{s}) ; 7.68(2 \mathrm{H}, \mathrm{s}) ; 7.78(2 \mathrm{H}, \mathrm{s}) ; 8.72$ $(4 \mathrm{H}, \mathrm{s})$.

\section{Synthesis of C-4-hydroxy-3-methoxyphenylcalix[4] pyrogallolarene (3d)}

Pyrogallol (1.89 g; $0.015 \mathrm{mmol})$, vanillin (2.28 g; $0.015 \mathrm{mmol})$, ethanol $(30 \mathrm{~mL})$, and $\mathrm{HCl} 37 \%(1 \mathrm{~mL})$ were reacted according to the method of preparation of compound $\mathbf{3 a}$ to give compound $\mathbf{3} \mathbf{d}$ as a purple solid in $53 \%$ (m.p. $\left.>290{ }^{\circ} \mathrm{C}\right)$. FTIR $\left(\mathrm{KBr}, v ; \mathrm{cm}^{-1}\right):(-\mathrm{OH}) 3387$, $\left(\mathrm{C}_{s p^{3}} \mathrm{H}\right)$ 2924, (C=O) 1700-1680, (C=C aromatic) 1612 and $1512,(\mathrm{C}-\mathrm{H}) 1458,\left(-\mathrm{CH}_{2^{-}}\right) 1373$, (C-O phenol) 1273 , (C-O ether) 1040. ${ }^{1} \mathrm{H}-\mathrm{NMR}$ (DMSO- $\left.d_{6} ; 500 \mathrm{MHz}\right) \delta$ (ppm): $3.42(12 \mathrm{H}, \mathrm{s}) ; 5.52(4 \mathrm{H}, \mathrm{s}) ; 5.55(4 \mathrm{H}, \mathrm{s}) ; 7.22(4 \mathrm{H}, \mathrm{s})$; $7.46(2 \mathrm{H}, \mathrm{s}) ; 7.96(4 \mathrm{H}, \mathrm{s}) ; 6.08(\mathrm{~J}=10 \mathrm{~Hz}, 4 \mathrm{H}, \mathrm{d}) ; 6.31(\mathrm{~J}=10$ $\mathrm{Hz}, 4 \mathrm{H}, \mathrm{d}) ; 7.63(8 \mathrm{H}, \mathrm{s}) ; 7.72(4 \mathrm{H}, \mathrm{s}) .{ }^{13} \mathrm{C}-\mathrm{NMR}$ (DMSO;
$500 \mathrm{MHz}) \delta$ (ppm): 44 (C methoxy moiety of vanillin); 56 (C of methylene bridge); 110-120 and 133 (C of vanillin's aromatic ring un-attached by methoxyl or hydroxyl group); 123 and 132 (C of pyrogallol's aromatic ring un-attached by hydroxyl group); 136 and 142 (C of pyrogallol's aromatic ring attached by hydroxyl group); 145 and 148 (C of vanillin's aromatic ring attached by hydroxyl and methoxyl, respectively). LCMS $[\mathrm{M}]^{+}$: $1040.90(\mathrm{~m} / \mathrm{z})$.

\section{Synthesis of C-4-hydroxyphenylcalix[4]resorcinaryl dodecabenzoate (4a)}

Compound 3a (0.48 g; $0.5 \mathrm{mmol})$ was dissolved in $8 \mathrm{~mL}$ of pyridine and afterward, $1.39 \mathrm{~mL}(0.5 \mathrm{mmol})$ benzoyl chloride was added. The mixture was placed in a cooling bath. The mixture was stirred and heated at $90{ }^{\circ} \mathrm{C}$ for $10 \mathrm{~h}$. After the mixture cools off, $300 \mathrm{~mL}$ of distilled water was added. The precipitate formed was filtered, washed with water and dried in a desiccator to give compound $4 \mathrm{a}$ as a orange solid in $68 \%$ yield (m.p. > $\left.237^{\circ} \mathrm{C}\right)$. FTIR $\left(\mathrm{KBr}, v ; \mathrm{cm}^{-1}\right):\left(\mathrm{C}_{\left.s p^{3}-\mathrm{H}\right)} 2924\right.$ and 2854, $(\mathrm{C}=\mathrm{C}) 1604$ and 1512, (C-H) 1427, (C=O ester) 1720, (C-O) 1265. ${ }^{1} \mathrm{H}-\mathrm{NMR}\left(\mathrm{CDCl}_{3} ; 500 \mathrm{MHz}\right) \delta$ (ppm): 4.03 (proton of calix[4] resorcinarene methine bridge, $\mathrm{m}$ ); 6.58 and 8.20 (proton of aromatic resorcinol, b); 6.99, 7.40 and 7.45 (proton of aromatic benzoyl, b); 6.80 and 7.91 (proton aromatic of benzaldehyde, b).

\section{Synthesis of C-4-hydroxy-3-methoxyphenylcalix[4] resorcinaryl dodecabenzoate (4b)}

Compound $\mathbf{4 b}$ was synthesized using the same procedure as that of calix $\mathbf{4 a}$ in which $\mathbf{3 b}(4.30 \mathrm{~g} ; 0.5$ mmol), benzoyl chloride $(1.39 \mathrm{~mL} ; 0.5 \mathrm{mmol})$ and pyridine $(8 \mathrm{~mL})$ were used to afford $\mathbf{4 b}$ as a reddishorange solid in $54 \%$ yield (m.p. $241^{\circ} \mathrm{C}$ ). FTIR ( $\mathrm{KBr}$, v; $\left.\mathrm{cm}^{-1}\right)$ : (C=O ester) 1720, (C-O) 1265, $\left(\mathrm{C}_{s p^{3-}} \mathrm{H}\right) 2924$ and 2854, (C=C aromatic) 1604 and 1512, (C-H) 1427, ($\left.\mathrm{CH}_{3}\right)$ 1373. ${ }^{1} \mathrm{H}-\mathrm{NMR}\left(\mathrm{CDCl}_{3} ; 500 \mathrm{MHz}\right) \delta(\mathrm{ppm}): 5.72$ (proton of calix[4]resorcinarene methylene bridge, b); 6.32 and 8.22 (proton of aromatic resorcinol, b); 7.11, 7.46 and 7.50 (proton of aromatic benzoyl, b); 6.62, 7.80 and 8.05 (proton of vanillin aromatic moiety, b); 3.53 (proton of methoxy moety of the vanillin, $b$ ). 


\section{Synthesis of C-4-hydroxyphenylcalix[4]pyrogallolarene hexadeca-cinnamate (4c)}

Compound 3c (0.46 g; $0.5 \mathrm{mmol})$ was dissolved in 8 $\mathrm{mL}$ of pyridine and afterward $2.67 \mathrm{~g}(16 \mathrm{mmol})$ cinnamoyl chloride was added. The mixture was placed in a cooling bath. The mixture was stirred and heated at $90{ }^{\circ} \mathrm{C}$ for 10 h. After the mixture cools off, $300 \mathrm{~mL}$ of distilled water was added. The precipitate formed was filtered, washed with water and dried in a desiccator to give compound $4 \mathrm{c}$ as a white solid in $97 \%$ yield (m.p. $>290^{\circ} \mathrm{C}$ ). FTIR ( $\mathrm{KBr}$, $\left.v ; \mathrm{cm}^{-1}\right):\left(\mathrm{C}_{s p^{3}-\mathrm{H}}\right) 2924,(\mathrm{C}=\mathrm{O}$ ester $) 1735,(\mathrm{C}=\mathrm{C}$ aromatic $)$ 1612 and 1512, (C-H) 1458, (- $\left.\mathrm{CH}_{2-}\right)$ 1442, (C-O ester) 1311-1134. ${ }^{1} \mathrm{H}-\mathrm{NMR}$ (DMSO- $\left.d_{6} ; 500 \mathrm{MHz}\right) \delta$ (ppm): 6.25 (s) and $7.76(\mathrm{~m})$ (Proton of the alkene of the cinnamate moiety); 7.10-7.51 (Proton of aromatic ring of cinnamate moiety, m); 5.65 (Proton of methine bridge, s); 6.47-6.77 (Proton of the aromatic ring of the pyrogallol and 4hydroxybenzaldehyde moieties, $\mathrm{m}$ ).

\section{Synthesis of C-4-hydroxy-3-methoxyphenylcalix [4] pyrogallolarene hexadecacinammate (4d)}

Compound 4d was synthesized using the same procedure as that of calix $4 \mathbf{c}$ in which $3 \mathbf{d}(0.52 \mathrm{~g} ; 0.5$ $\mathrm{mmol})$, cinnamoyl chloride $(2.67 \mathrm{~g} ; 16 \mathrm{mmol})$ and pyridine $(8 \mathrm{~mL})$ were used to afford $\mathbf{4 d}$ as an orange solid in $90 \%$ yield. FTIR $\left(\mathrm{KBr}, v ; \mathrm{cm}^{-1}\right):\left(\mathrm{C}_{s p^{3}-\mathrm{H}}\right) 2924,(\mathrm{C}=\mathrm{O}$ ester) $1735,\left(\mathrm{C}=\mathrm{C}\right.$ aromatic) $1635,(\mathrm{C}-\mathrm{H}) 1458,\left(-\mathrm{CH}_{2}-\right)$ 1442, (C-O ester) 1311, (C-O ether) 1134. ${ }^{1} \mathrm{H}-\mathrm{NMR}$ (DMSO- $\left.d_{6} ; 500 \mathrm{MHz}\right) \delta$ (ppm): 3.51 (Proton of methoxy moiety of the vanillin, s); 5.64 (Proton of methylene bridge, s); 6.35-6.75 (Proton of aromatic vanillin and pyrogallol, $\mathrm{m}$ ); 7.24-7.88 (Proton of cinnamate moiety, b); $6.26(\mathrm{~s})$ and $7.89(\mathrm{~m})$ (Proton of the alkene of the cinnamate moiety).

\section{Antioxidant activity test (DPPH) of synthesized compounds 3a-d}

Antioxidant activity was assessed using the 2,2Diphenyl-1-picrylhydrazyl (DPPH) free radical inhibition assay. Several concentrations of compounds $3 \mathbf{a}-\mathbf{d}(0,5,10$, 25 and $50 \mu \mathrm{g} / \mathrm{mL}$ ) in DMSO were prepared for the sample solution. To each sample solution $(0.2 \mathrm{~mL}), 1 \mathrm{~mL}$ of DPPH $(100 \mu \mathrm{g} / \mathrm{mL})$ and $3.8 \mathrm{~mL}$ of ethanol were added. The mixture was shaken for $30 \mathrm{~min}$. The absorbance was measured at a wavelength of $517 \mathrm{~nm}$. The percentage of the inhibition was calculated using the Eq. 1.

\%inhibition $=\frac{\left(\mathrm{A}_{\text {blank }}-\mathrm{A}_{\text {sample }}\right)}{\mathrm{A}_{\text {blank }}} \times 100 \%$

and then the linear plot of \%inhibition versus concentration was analyzed (Eq. 2).

$\mathrm{y}=\mathrm{a}+\mathrm{bx}$

where $\mathrm{x}$ is the concentration of the measured substance and $y$ is the $\%$ inhibition. Meanwhile, the $\mathrm{IC}_{50}$ value was determined as the $\mathrm{x}$ value of this equation when $\mathrm{y}$ was equal to $50 \%$.

\section{Sunscreen activity test (in vitro) synthesized compounds (4a-d)}

The compounds $\mathbf{4 c - d}(0.5 \mathrm{mg})$ were respectively dissolved into $10 \mathrm{~mL}$ chloroform while compounds $\mathbf{4 a - b}$ were respectively dissolved into $10 \mathrm{~mL}$ DMSO in order to obtain the test solutions with a concentration of $50 \mu \mathrm{g} / \mathrm{mL}$. The absorbance of these test solutions was respectively read at a wavelength of 200-400 $\mathrm{nm}$ using UV-Vis spectrophotometer. Chloroform was used as a blank solution for compounds $\mathbf{4 c - d}$ while DMSO was used as a blank solution for compounds $\mathbf{4 a - b}$. These compounds showing a strong absorbance in UV-B and UV-A area were further tested their photostability.

\section{Photostability test of compounds (4c-d)}

Photostability test was performed according to the methodology described by Chawla et al. [16] and Budiana [18]. However, in this report, the photostability test was only conducted in the UV-B region. Compounds $4 \mathbf{c}-\mathbf{d}(1 \mathrm{mg})$ were respectively placed into a $10 \mathrm{~mL}$ of volumetric flask. Chloroform was subsequently added to the mark. Then, these solutions were respectively diluted to obtain a solution with concentration of $8 \mu \mathrm{g} / \mathrm{mL}$. Afterward, $4 \mathrm{~mL}$ of each of the diluted solution was moved into six $10 \mathrm{~mL}$ vials and radiated with UV-B with the intensity of $0.283 \mathrm{~mW} / \mathrm{cm}^{2}$ for $0,5,15,30,60$, and $90 \mathrm{~min}$. After radiation was completed, the absorption of $\mathbf{4 c - d}$ solutions was measured at $\lambda$ 200-400 $\mathrm{nm}$ using a UV-Vis spectrophotometer. Spectra of these test solutions for respectively $\mathbf{4 c}$ and $\mathbf{4 d}$ in the given time range are compared in order to find the change of spectral 
absorption of the $\mathbf{4 c - d}$ derivative compounds. The potential compounds to be developed as sunscreen compounds or more specifically UV-B protectors are those having absorbance which did not significantly decrease after being exposed to UV-B rays.

\section{- RESULTS AND DISCUSSION}

The synthesis of all compounds was performed according to Fig. 1 (3a-b and $\mathbf{4 a - b}$ ) and 2 (3c-d and $\mathbf{4 c - d}$ ). The synthesized compounds were identified by FT-IR, ${ }^{1} \mathrm{H}$ $\mathrm{NMR},{ }^{13} \mathrm{C} \mathrm{NMR}$, and LC-MS which proved that the expected products have already been produced. The spectroscopic data of the compounds are as presented in the experimental section.

The condensation of resorcinol with respectively 4-hydroxybenzaldehyde and vanillin to generate compounds $\mathbf{3} \mathbf{a}$ and $\mathbf{3} \mathbf{b}$ were strongly proved by the presence of methine bridge in ${ }^{1} \mathrm{H}-\mathrm{NMR}$ spectra of compound 3a $(\delta: 5.41 \mathrm{ppm})$ and $3 \mathbf{b}(\delta: 5.40 \mathrm{ppm})$. Likewise, the condensation of pyrogallol with respectively 4-hydroxy benzaldehyde and vanillin to form compounds $\mathbf{3} \mathbf{c}$ and $\mathbf{3} \mathbf{d}$ were strongly indicated by

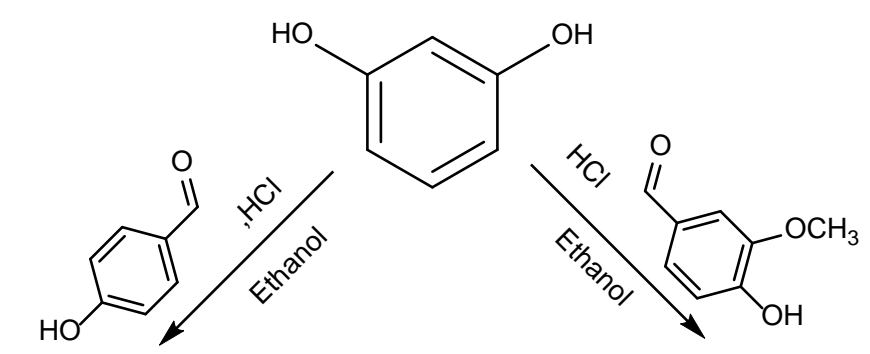<smiles>Oc1ccc(C(c2ccc(O)cc2)c2cc(C(c3ccc(O)cc3)c3cc(C(c4ccc(O)cc4)c4cc(C(c5ccc(O)cc5)c5cc(O)c(O)cc5O)c(O)cc4O)c(O)cc3O)c(O)cc2O)cc1</smiles>

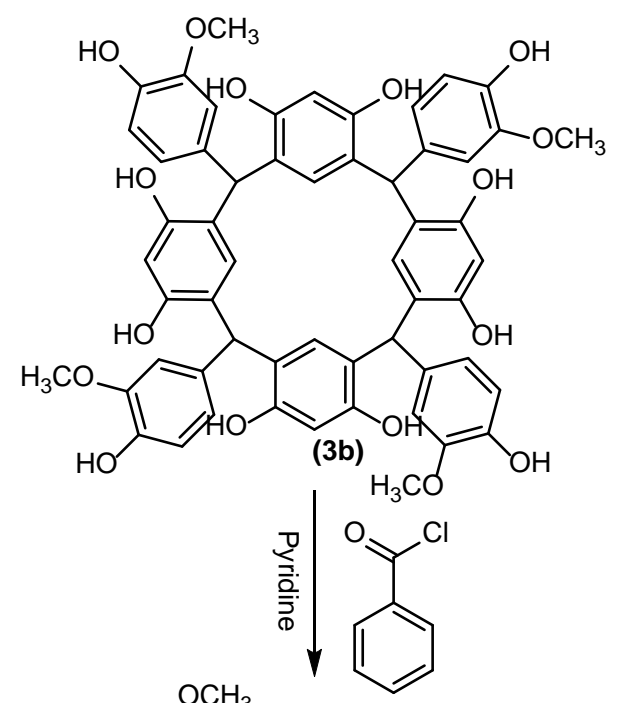

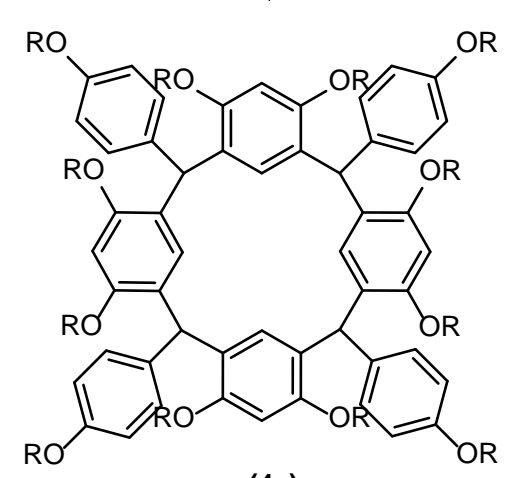

(4a) (3a)<smiles>O=C(Cl)c1ccccc1</smiles>

$\mathrm{R}: \mathrm{Ph}-\mathrm{C}(\mathrm{O})-$

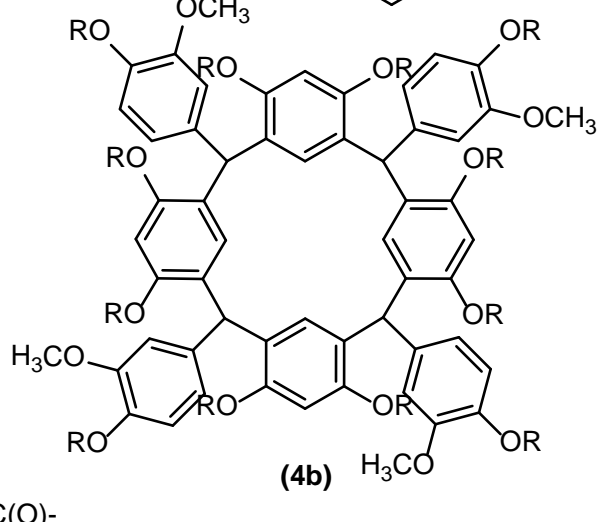

(4b)

Fig 1. Synthetic scheme of compounds $\mathbf{3} \mathbf{a}-\mathbf{b}$ and $\mathbf{4 a}-\mathbf{b}$ 


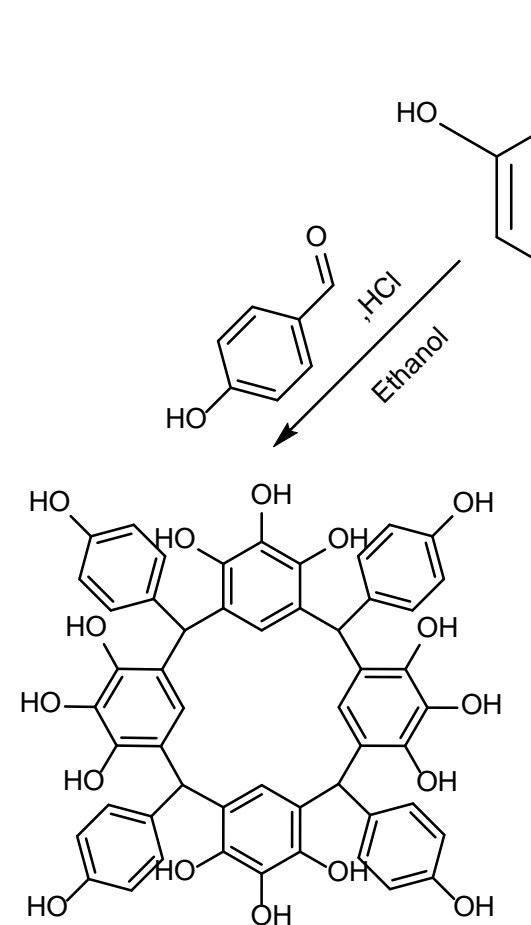

(3c)<smiles>O=C(Cl)/C=C/c1ccccc1</smiles>

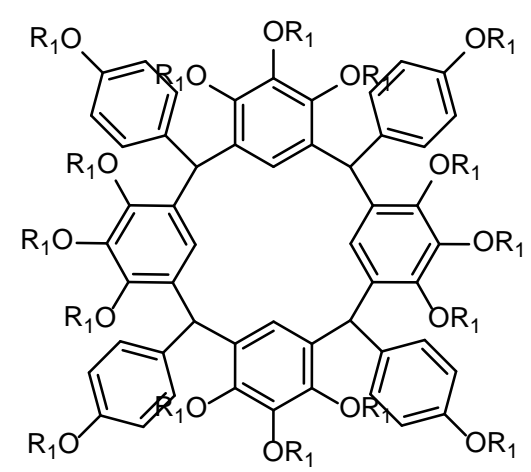

(4c)

$$
\mathrm{R}_{1}: \mathrm{PhCH}=\mathrm{CHC}(\mathrm{O})-
$$

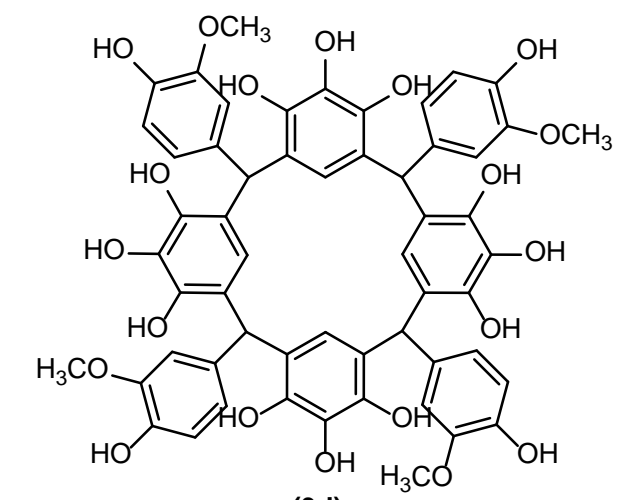

(3d)<smiles>O=C(Cl)/C=C/c1ccccc1</smiles>

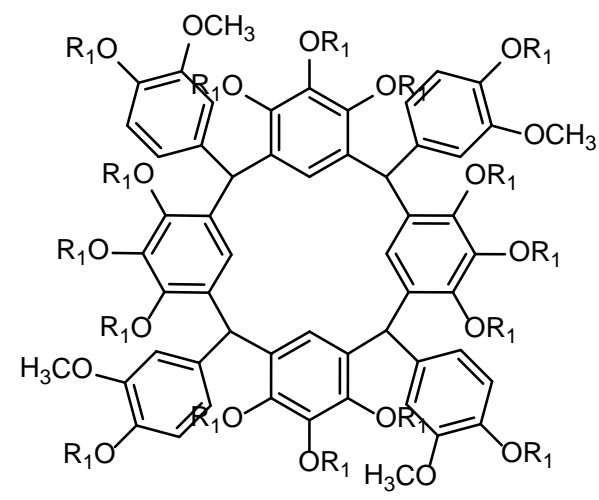

(4d)

Fig 2. Synthetic scheme of compounds $3 c-d$ and $4 c-d$

the presence of methine bridge in ${ }^{1} \mathrm{H}-\mathrm{NMR}$ spectra of compound $3 \mathrm{c}(\delta: 5.52 \mathrm{ppm})$ and $3 \mathrm{~d}(\delta: 5.55 \mathrm{ppm})$. The presence of methine bridge was clear proof that the calixarene derivatives have been formed [19]. Furthermore, the absence of the aldehyde carbonyl $\left(1700-1680 \mathrm{~cm}^{-1}\right)$ in the FT-IR data of compounds 3a-d also indicated that the aldehyde carbonyl moiety of either 4-hydroxybenzaldehyde or vanillin were successfully transformed to be methine bridge. Another evidence that demonstrated the formation of $\mathbf{3} \mathbf{d}$ was the presence of the $\left[\mathrm{M}^{+}\right]$in LC-MS result of this compound. In addition, the LC-MS results also showed that the 
trimer of C-4-hydroxy-3-methoxyphenylcalix[4]resorcin arene fragment as a base peak which strongly indicated the $\mathbf{3 b}$ compound has been synthesized.

The esterification reaction of either compounds $3 c-$ d with cinnamoyl chloride to form respectively compounds $\mathbf{4} \mathbf{c}-\mathbf{d}$, or compounds $\mathbf{3 a - b}$ with benzoyl chloride to form compounds $\mathbf{4 a - b}$ was proven by the presence of ${ }^{1} \mathrm{H}-\mathrm{NMR}$ of the cinnamoyl moiety in compounds $\mathbf{4 c - d}$ and also benzoyl moiety in compounds 4a-b (served in the experimental section). However, the coupling constant of the compounds 4a-d ${ }^{1} \mathrm{H}-\mathrm{NMR}$ spectra cannot be served because the form of the ${ }^{1} \mathrm{H}-\mathrm{NMR}$ spectra of the 4a-b was multiplet (coincide with one another) while $\mathbf{4 c - d}$ were broad form instead of the line form.

The multiplet spectra of the compounds $\mathbf{4 a - b}$ were probably caused by the presence of hydrogen of many aromatic rings. While the broad spectra of the compounds $\mathbf{4 c - d}$ occurred because of its complex hydrogen bonding interaction. Furthermore, the presence of many aromatic rings conjugated with alkene group in the compounds $\mathbf{4 c - d}$ which interact each other by $\pi-\pi$ interaction [20-21] that strongly influenced and rapidly changed time by time the electron density of each aromatic ring, thus electron shielding of proton would also influenced and changed rapidly and therefore the $4 c-$ d spectra were more likely as broad than line spectra. In addition, the presence of $\mathrm{C}=\mathrm{O}$ (ester) in the FT-IR spectra of compounds $4 \mathbf{c}-\mathbf{d}$ at $1735 \mathrm{~cm}^{-1}$ and compounds $4 \mathbf{a}-\mathbf{b}$ at $1720 \mathrm{~cm}^{-1}$ were strongly indicated that these compounds have been formed.

\section{Antioxidant Activity}

Antioxidant activity test of C-arylcalix[4]resorcin arene $\mathbf{3 a - b}$ and C-arylcalix[4]pyrogallolarene $\mathbf{3 c}$-d were performed using the DPPH free radical inhibition assay. This method was chosen because it is a fast, simple and accurate method. Moreover, the method can be applied to the samples in small quantities. DPPH is a purple organic compound containing nitrogen radicals with strong absorbance at a maximum wavelength of $517 \mathrm{~nm}$. When DPPH reacts with the antioxidant compound, DPPH would be reduced and its color would turn yellow [22].
The qualitative DPPH method could be used to determine the $\mathrm{IC}_{50}$ value based on the obtained linear regression graph of Eq. 2. The $\mathrm{IC}_{50}$ is a parameter utilized to determine antioxidant activity. The $\mathrm{IC}_{50}$ is the concentration of antioxidant that inhibits $50 \%$ of DPPH free radical activities. The $\mathrm{IC}_{50}$ values come from the linear regression graph of the inhibition percentage of the absorption of the sample against blank reagent measured at $517 \mathrm{~nm}$ [23]. The results of the antioxidant activity test of the compounds $3 \mathrm{a}-\mathrm{d}$ are presented in Table 1.

The test result showed that C-4-arylcalix[4] resorcinarene $\mathbf{3} \mathbf{a}-\mathbf{b}$ are a very strong antioxidant agent, especially when compared to the $\mathrm{IC}_{50}$ values of the two derivative compounds of $\mathrm{C}$-arylcalix[4]pyrogallolarene 3c-d. According to [24], level of antioxidant strength is divided into four levels, which are very strong $\left(\mathrm{IC}_{50}<\right.$ $50 \mu \mathrm{g} / \mathrm{mL}$ ), strong ( IC $_{50}: 50-100 \mu \mathrm{g} / \mathrm{mL}$ ), moderate $\left(\mathrm{IC}_{50}\right.$ : $101-150 \mu \mathrm{g} / \mathrm{mL}$ ), and weak ( $\mathrm{IC}_{50}: 250-500 \mu \mathrm{g} / \mathrm{mL}$ ). This indicated that the antioxidant activity of compound $\mathbf{3 b}$ is stronger than that of $\mathbf{3 a}$. This is because compound $\mathbf{3 b}$ has hydroxyl and methoxyl substituents which act as electron donors.

The presence of the more electron donating groups led compound $\mathbf{3} \mathbf{b}$ to have the greater inductive effect than compound 3a, thus the radical electron stability of compound $\mathbf{3 b}$ would also be greater than $\mathbf{3 a}$ [25] and therefore the antioxidant activity of compound $\mathbf{3 b}$ is stronger than that of $\mathbf{3 a}$. Nonetheless, the antioxidant activity of compound $\mathbf{3} \mathbf{c}-\mathbf{d}$ was lower than those of $\mathbf{3 a} \mathbf{a}-\mathbf{b}$ even though 3c-d have more hydroxyl groups than $\mathbf{3 a - b}$. This was probably due to the existence of more effective intramolecular hydrogen bonding in the pyrogallol system of $\mathbf{3 c}-\mathbf{d}$ in comparison to that of resorcinol system

Table 1. $\mathrm{IC}_{50}$ values of the antioxidant activity test using DPPH method

\begin{tabular}{lcl}
\hline Compounds & $\mathrm{IC}_{50}$ Values & Antioxidant Activity \\
\hline BHT & 8.25 & Very Strong \\
3a & 22.68 & Very Strong \\
3b & 17.24 & Very Strong \\
3c & 88.20 & Strong \\
3d & 79.60 & Strong \\
\hline
\end{tabular}


of $\mathbf{3 a}-\mathbf{b}$ leading to the decreased ability to generate oxy radical of $\mathbf{3 c}-\mathbf{d}$ compared to that of $\mathbf{3 a}-\mathbf{b}$.

\section{Sunscreen Assay}

Test of compounds 3a-d and $\mathbf{4 a - d}$ as sunscreen was performed in two stages including UV absorption measurements using UV-Vis spectrophotometer and a photostability test using UV-B radiation. Both tests were conducted to investigate the potential use of compound 3a-d and 4a-d as a sunscreen compound. Analysis of UV absorption of 3a-d and $\mathbf{4 a - d}$ were conducted using a UVVis spectrophotometer. The tested compounds 3a-d and 4a-d have low solubility in solvents commonly used for $\mathrm{UV}$-Vis measurement (ethanol, isopropanol, and water), thus these compounds $\mathbf{3 a - b}$ and $\mathbf{4} \mathbf{c}-\mathbf{d}$ were dissolved in chloroform $\left(\mathrm{CHCl}_{3}\right)$ while compounds $3 \mathbf{c}-\mathbf{d}$ and $\mathbf{4 a - b}$ were dissolved in DMSO during the absorption measurements in UV-Vis. Actually, chloroform and DMSO are not recommended to be used for UV measurements because these solvents have electronic absorption in the UV area (chloroform: cut off 260 and $240 \mathrm{~nm}$; DMSO: $265 \mathrm{~nm}$ ). Nevertheless, the use of a double beam UV-Vis spectrophotometer with respectively solvent (DMSO or chloroform) as a blank solution and the baseline correction performed prior to the measurement is believed to keep the measurement accuracy intact both qualitatively and quantitatively.

In this study, the activity of the synthesized compound as the UV radiation absorber could be seen from the pattern of the compound absorbance when analyzed with UV-Vis spectrophotometer. Compounds with high-intensity absorption at UV-A and UV-B wavelength regions have good sunscreen activity.

Sun Protection Factor (SPF) is a number indicating the level of protection to the sunburn caused by UV radiation that could be provided by a compound. The determination of the SPF number in this study was obtained from UV-Vis spectrophotometer experiments. The SPF number would decrease when the concentration of the sunscreen compound is lowered since the absorption of the compound would decrease with the decrease of concentration. The SPF number is more about the strength of sunscreen against sunburn than about the chronic effects of the sun radiation [26].

The analysis of UV absorption and SPF values of the compounds 3a-d and $\mathbf{4 a - d}$ were served in Table 2. It showed that the compounds $\mathbf{3 a}-\mathbf{b}$ only have the adsorption at UV-C region, but the compounds $\mathbf{3 c - d}$ have the adsorption at both UV-B and UV-C region. It occurred because the compounds $\mathbf{3 c}$-d which were synthesized from pyrogallol have more electron donating groups $(-\mathrm{OH})$ than the compounds $\mathbf{3} \mathbf{a}-\mathbf{b}$ which were synthesized from resorcinol. This electron donating group gave the more variation of the excited state of an electron with a variation of wavelength, thus the more containing electron donating groups, it would have more variation and broader band of absorbed wavelength. Therefore, the compounds $\mathbf{3 c}$-d have more broadband spectrum (UV-B and UV-C) than compounds 3a-b (UV-C).

Likewise, the compounds 4c-d which were synthesized from compounds $\mathbf{3 c - d}$ have more broadband spectrum (UV-B and UV-C region) compared to compounds $\mathbf{4 a - b}$ (only UV-C region) which were synthesized from compounds $\mathbf{3 a - b}$. In addition, the SPF values of compounds $\mathbf{4 c - d}$ were greater than compounds $\mathbf{3 c}$-d. It occurred because compounds 4c-d which have the cinnamoyl moiety while the compounds $\mathbf{3 c - d}$ do not have. This cynnamoil moiety could give the extension of conjugation of the $\pi$ electron that lower the gap between HOMO and LUMO, thus the probability of electron excitation would increase which

Table 2. $\lambda_{\max }$ and SPF values of synthesized compounds

\begin{tabular}{|c|c|c|c|}
\hline \multirow{2}{*}{ Compound } & \multicolumn{2}{|c|}{$\lambda_{\max }(\mathrm{nm})$} & \multirow{2}{*}{ SPF } \\
\hline & UV-B & UV-C & \\
\hline $3 \mathbf{a}$ & N/A & 288 & N/A \\
\hline $3 b$ & N/A & 275 & N/A \\
\hline $3 c$ & 291 & 275 & 1.6 \\
\hline $3 d$ & 291 & 279 & 1.7 \\
\hline $4 a$ & N/A & 290 & N/A \\
\hline $4 \mathrm{~b}$ & N/A & 282 & N/A \\
\hline $4 c$ & 291 & 280 & 32.4 \\
\hline $4 d$ & 291 & 280 & 152 \\
\hline
\end{tabular}



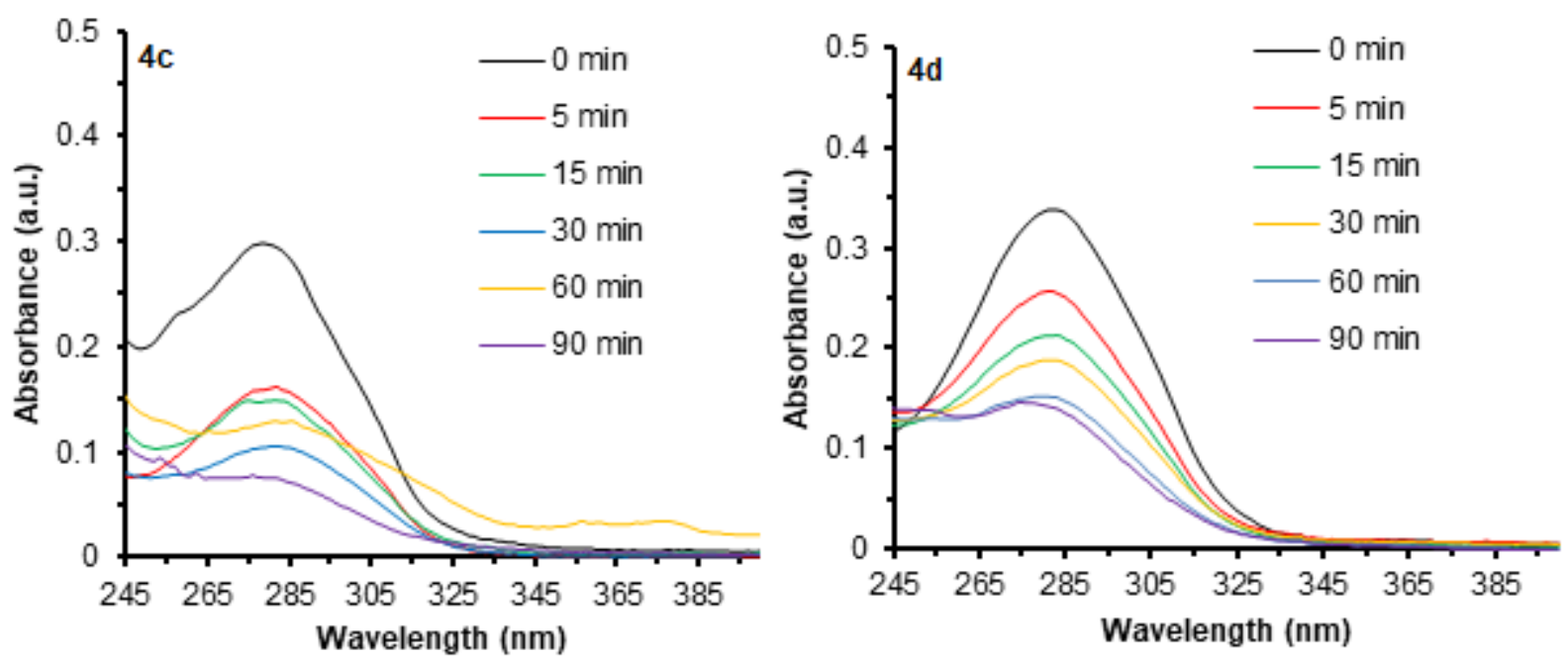

Fig 3. Photostability test of the $4 \mathrm{c}$ and $4 \mathrm{~d}$ derivative compounds

means that the absorptivity constant of the compound would also increase. This increase of adsorptivity would also increase the SPF values for each molar of the compound.

According to the American Academy of Dermatology, a good sunscreen is a compound that has a broad spectrum, could absorb UV-B and UV-A rays has high SPF (> 30) at a concentration that does not affect fibroblast cells and also does not dissolve in water within 40-80 min. The result of electronic spectrum measurement revealed that compounds $\mathbf{4 c}$-d fulfill these criteria.

After determining the capability of compound $\mathbf{4 c - d}$ in absorbing the dangerous radiation of UV rays, the photostability test was performed to find out the stability of these compounds against UV ray exposure. A good sunscreen should have high stability, means that the structure of the sunscreen compounds will not change after being exposed to the dangerous UV rays. The change of structure could alternate the pattern of electronic spectrum of a compound. When an organic compound absorbs UV radiation, there will be electron excitations to the excited state. The faster excitation process, the better photostability of the compound. If the electron excitation did not happen, thus it will be bond-breaking to form new bonds which deliver to a new different structure. In this case, the faster a molecule reaching the excited state, the more stable the compound during that short time, the molecule will not have time to react with other species [27]. The organic sunscreen compound is relatively less stable against the exposure to the dangerous UV radiation. Therefore, a photostability test should be conducted to determine the durability and duration of protection that sunscreen compounds could provide against UV radiation.

The results of the photostability test of these two compound $\mathbf{4 c - d}$ are presented in Fig. 3. The results of the photostability test showed that the absorbance of the all tested compounds decreased after being radiated using UVB rays with the intensity of $0.287 \mathrm{~mW} / \mathrm{cm}^{2}$ for 5,10 , 15, 30, 60 and $90 \mathrm{~min}$. The two derivative compounds of C-arylcalix[4]pyrogallolarylcinnamate $4 \mathbf{c}-\mathbf{d}$ pose a relatively poor photostability. The absorbance of both cinnamate derivative compounds decreased like $65 \%$ for $3 \mathrm{c}$ and $44 \%$ for $\mathbf{3 d}$ after being radiated for $30 \mathrm{~min}$. The results of the photostability test also showed there was a shift on $\lambda_{\max }$. The instability of the cinnamate derivative compounds occurs because the compounds react through cis-trans isomerization and [2+2] cycloaddition to produce other species [28]. The cis-trans isomerization is the transformation of geometry which need relatively low energy and it was frequently found, however, the $[2+2]$ cycloaddition could only occur with the presence of ho. The ho would excite the electron from 


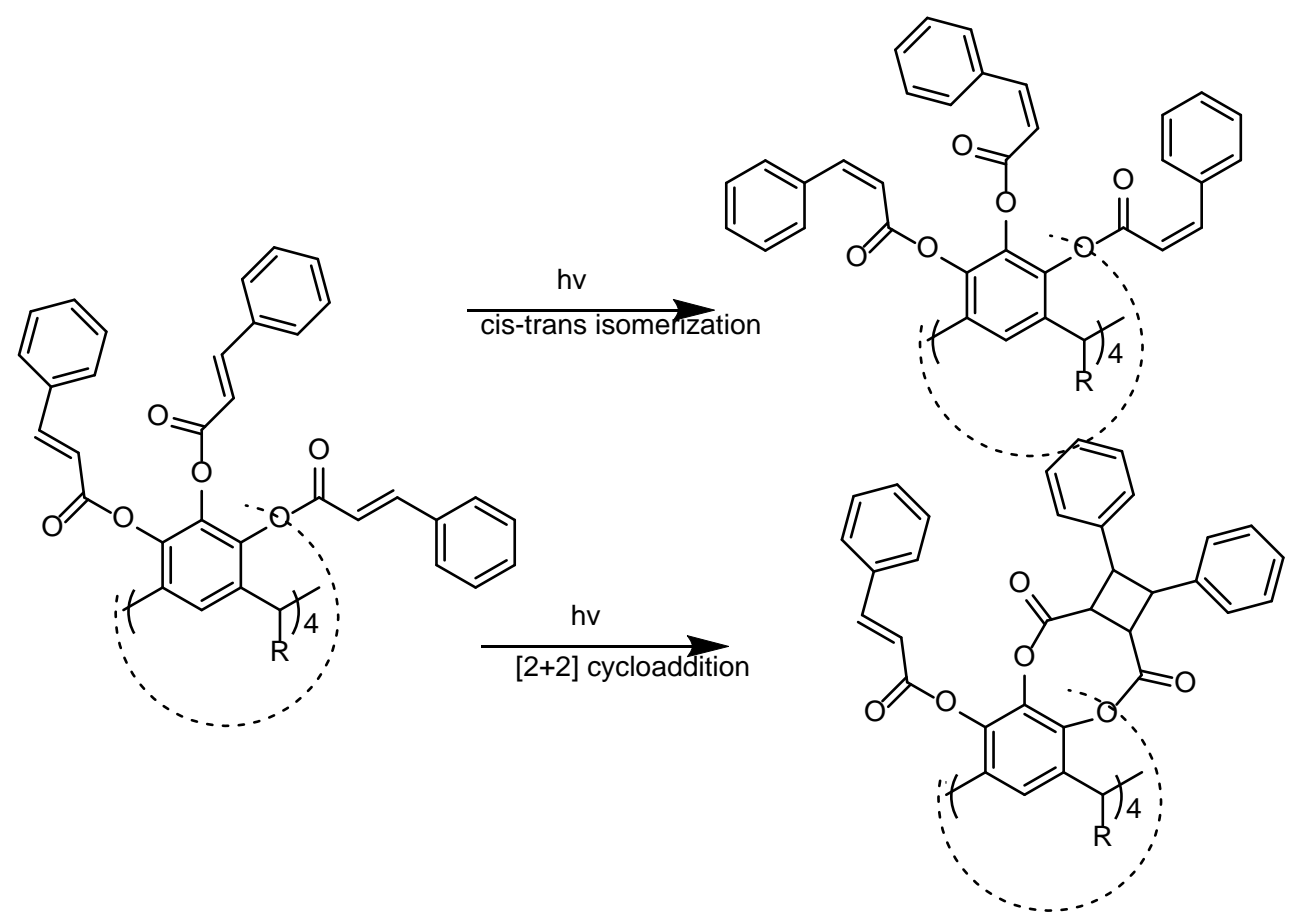

Fig 4. Prediction of photodegradation reaction of compound $4 \mathrm{c}-\mathrm{d}$

HOMO to LUMO and rearrange the phase of molecular orbital which causes bond breaking of the $\pi$ bonding to form another $\sigma$ bond [29].

The shift of $\lambda_{\max }$ of the two cinnamate derivative compounds is predicted to happen due to the formation of new chromophore groups from the produced photodegradation product, such as enoate ester and dienoate groups [28]. Thus, the decrease of electronic absorbance of these two C-arylcalix[4]pyrogallolarene cinnamate $\mathbf{4 c}$ and $\mathbf{4 d}$ compound are believed to work with the same mechanism. The simple version of the degradation of C-arylcalix[4]pirogallolarene cinnamate mechanism is presented in Fig. 4.

\section{- CONCLUSION}

Compound 3a-b are strong antioxidant agents, while compound $\mathbf{3 c}$-d belong to the group of weak antioxidant agents. Compound $\mathbf{4 c}$ and $\mathbf{4 d}$ possess relatively similar absorbance with $\lambda_{\max }$ of $291 \mathrm{~nm}$ (UV-B). The SPF values of $\mathbf{4 c}$ and $\mathbf{4 d}$ are 32.4 and 15.2, respectively, showing that the compounds have the potential to be developed as an active sunscreen.

\section{- REFERENCES}

[1] Qian, Y., Qiu, X., and Zhu, S., 2014, Lignin: A nature-inspired sun blocker for broad-spectrum sunscreens, Green Chem., 17 (1), 320-234.

[2] Osterwalder, U., and Herzog, B., 2008, "Chemistry and Properties of Organic and Inorganic UV Filters" in Clinical Guide to Sunscreen and Photoprotection, Eds., Lim, H.W., and Draelos, Z.D., $1^{\text {st }}$ ed., CRC Press, Boca Raton, FL, 11-38.

[3] Manaia, E.B., Kaminski, R.C.K., Correal, M.A., and Chiavaccil, L.A., 2013, Inorganic UV filters, Braz. J. Pharm. Sci., 49 (2), 201-209.

[4] Boyd, A.S., Naylor, M., Cameron, G.S., Pearse, A.D., Gaskell, S.A., and Neldner, K.H., 1995, The effects of chronic sunscreen use on the histologic changes of dermatoheliosis, J. Am. Acad. Dermatol., 33 (6), 941-946.

[5] van Praag, M.C.G., Roza, L., Boom, B.W., OutLuitjing, C., Henegouwen, J.B.A.B, Vermeer, B.J., and Mommas, A.M., 1993, Determination of the photoprotective efficacy of a tropical sunscreen against UVB-induced DNA damage in human 
epidermis, J. Photochem. Photobiol., B, 19 (2), 129134.

[6] Liardet, S., Scaletta, C., Panizzon, R., Hohlfeld, P., and Laurent-Applegate, L., 2001, Protection against pyrimidine dimers, p53, and 8-hydroxy-2 $\beta$ deoxyguanosine expression in ultraviolet irradiated human skin by sunscreen: Difference between UVB + UVA and UVB alone sunscreen, J. Invest. Dermatol., 117 (6), 1437-1441.

[7] Dastidar, S.G., Bharath, P., and Roy, A., 2011, Rayleigh like scattering from silica-titania core-shell particles and their application in protection against harmful ultraviolet ray, Bull. Mater. Sci., 34 (2), 199206.

[8] Wong, C., and Currie, J., 2011, Teaching with CAChe Exercises on Molecular Modeling in Chemistry, Pacific University, Forest Grove, Oregon, 29, 36.

[9] Murphy, G.M., 1999, Sunblocks mechanisms of action, Photodermatol. Photoimmunol. Photomed., $15,34-36$.

[10] Duale, N., Olsen, A., Christensen, T., Butt, S.T., and Brunborg, G., 2010, Octyl methoxy cinnamate modelates gene expression and prevents cyclobutane pyrimidine dimer formation but not oxidative DNA damage in UV exposed human cell lines, Toxicol. Sci., 144 (2), 272-284.

[11] Chester, R., Sohail, M., Ogden, M.I., Mocerino, M., Pretsch, E., and De Marco, R., 2014, A calixarenebased ion-selective electrode for thallium(I) detection, Anal. Chim. Acta, 851, 78-86.

[12] Qureshi, I., Qazi, M.A., and Memon, S., 2009, A versatile calixarene for transportation systems and sensor technology, Sens. Actuators, B, 141 (1), 45-49.

[13] Sliwa, W., and Girek, T., 2010, Calixarene complexes with metal ions, J. Inclusion Phenom. Macrocyclic Chem., 66 (1-2), 15-41.

[14] Ludwig, R., 2000, Calixarenes in analytical and separation chemistry, Fresenius J. Anal. Chem., 367 (2), 103-128.

[15] Tabakci, M., Erdemir, S., and Yilmaz, M., 2007, Preparation, characterization of cellulose-grafted with calix[4]arene polymer for the adsorption of heavy metals and dichromate anions, J. Hazard. Mater., 148 (1-2), 428-435.

[16] Chawla, H.M., Pant, N., Kumar, S., Mrig, S., Srivastava, B., Kumar, N., and Black, D.S., 2011, Synthesis and evaluation of novel tetrapropoxy calix[4]arene enone and cinnamates for protection from ultraviolet radiation, J. Photochem. Photobiol. $B, 105$ (1), 25-33.

[17] Jiang, R., Roberts, M.S., Collins, D.M., and Benson, H.A.E., 1999, Absorption of sunscreens across human skin: An evaluation of commercial products for children and adults, Br. J. Clin. Pharmacol., 48 (4), 635-637.

[18] Budiana, I.G.N., 2015, Sintesis Seri BenzoatSinamat Kaliks[4]resorsinarena serta Uji Aktivitasnya sebagai Tabir Surya dan Adsorben Cr(III), Pb(III), dan Cd(II), Dissertation, Department of Chemistry, Universitas Gadjah Mada, Yogyakarta.

[19] Gutsche, C.D., and Levine, J.A., 1982, Calixarenes. 6. Synthesis of a functionalizable calix[4]arene in a conformationally rigid cone conformation, J. Am. Chem. Soc., 104 (9), 2652-2653.

[20] Li, W., and Wang, J., 2012, Interactions between lignin and urea researched by molecular simulation, Mol. Simul., 38 (13), 1048-1054.

[21] Imawan, A.C., Kurniawan, Y.S., Lukman, M.F., Jumina, Triyono, and Siswanta, D., 2018, Synthesis and kinetic study of the urea controlled release composite material: sodium lignosulfonate from isolation of wood sawdust-sodium alginate-tapioca, Indones. J. Chem., 18 (1), 108-115.

[22] Kikuzaki, H., Hisamoto, M., Hirose, K., Akiyama, K., and Taniguchi, H., 2002, Antioxidant properties of ferulic acid and its related compounds, J. Agric. Food Chem., 50 (7), 2161-2168.

[23] Molyneux, P., 2004, The use of stable free radical diphenylpicrylhydrazyl (DPPH) for estimating antioxidant activity, Songklanakarin J. Sci. Technol., 26 (2), 211-219.

[24] Setha, B., Gaspersz, F., Idris, A.P.S., Rahman, S., and Mailoa, M.N., 2013, Potential of seaweed Padina sp. 
as a Source of antioxidant, Int. J. Sci. Techol. Res., 2 (6), 221-224.

[25] Clayden, J., Greeves, N., and Warren, S.G., 2012, Organic Chemistry, $2^{\text {nd }}$ ed., Oxford University Press, Oxford.

[26] Ikhtiyati, N., 1998, Peranan Tabir Surya dalam Pencegahan Timbulnya Mutan pada biakan fibroblast yang mendapat pajanan sinar ultra violet B, Thesis, Faculty of Medicine, Universitas Gadjah Mada, Yogyakarta.
[27] Herzog, B., Wehrle, M., and Quass, K., 2009, Photostability of UV absorber Systems in Sunscreens, Photochem. Photobiol., 85 (4), 869-878.

[28] Schrader, A., Jakupovic, J., and Baltes, W., 1994, Photochemical Studies on trans-3-methyl butyl-4methoxycinnamate, J. Soc. Cosmet. Chem., 45 (1), 43-52.

[29] Junkers, T., 2015, [2+2] Photo-cycloadditions for polymer modification and surface decoration, Eur. Polym. J., 62, 273-280. 